\title{
Anti-Corruption Potential of Openness and Accessibility of Municipal Legal Acts
}

\author{
Irina A. Damm, Nikolai V. Shchedrin, \\ Olga V. Ronzhina, Evgenii A. Akunchenko \\ and Andrei V. Korkhov* \\ Siberian Federal University \\ 79 Svobodny, Krasnoyarsk, 660041, Russia
}

Received 14.02.2019, received in revised form 11.03.2019, accepted 14.03.2019

The article discusses openness of the results of the law-making activities that local government performs. Currently in Russia there is an electronic platform that allows to get access to the whole system of municipal legal acts in a unified form. In turn, legal regulation in this field is quite ambiguous and is not featured with framework of categories and concepts. The "Municipal Legal Acts of the Krasnoyarsk Krai" electronic information system is offered as a possible solution to the problem. Its structure includes two user interfaces, one of which is intended for the access of the citizens of the municipal unit and other interested persons to the database of municipal legal acts. The second one is intended for municipal officers, which form this database. The functional features of the electronic information system and the logic of a database building allow users to observe the current edition of a municipal legal act, view the history of the changes made to it, as well as track the links arising between acts in the process of law-making activities of local governments. Unlike most analogues, this system allows to store and publish legal acts with individual content, as well as, if necessary, to ensure their confidentiality. The implementation of such a system in the practice of municipalities has anticorruption potential, which is expressed in increasing the legal awareness of the population of the municipality, enhancing public control over the activities of local governments, as well as providing independent anti-corruption expertise of municipal regulations and their projects.

Keywords: local government, municipality, legal act, openness, accessibility, glasnost, publicity, transparency, electronic information system, corruption, prevention.

The reported study was funded by Krasnoyarsk Regional Fund for Science and Technology Development Support according to the research project: "Openness and Accessibility of Municipal Regulatory Legal Acts: the State and Ways of Ensuring”.

Research area: law.

(c) Siberian Federal University. All rights reserved

* Corresponding author E-mail address: idamm@sfu-kras.ru; nshedrin@sfu-kras.ru; oronzhina@sfu-kras.ru; eakunchenko@sfu-kras.ru; akorkhov@sfu-kras.ru

This work is licensed under a Creative Commons Attribution-NonCommercial 4.0 International License (CC BY-NC 4.0). 
Citation: Damm, I.A., Shchedrin, N.V., Ronzhina, O.V., Akunchenko, E.A., Korkhov, A.V. (2019). Anti-Corruption Potential of Openness and Accessibility of Municipal Legal Acts. J. Sib. Fed. Univ. Humanit. soc. sci., 12 (3), 378-392. DOI: 10.17516/1997-1370-0400

\section{Introduction}

In the modern conditions of the information society, the rights and freedoms of man and citizen depend on the level of openness of public administration. Unhindered public access to the information on the activities of government authorities is a factor that, on the one hand, impedes targeted unlawful activities of officials, and on the other, contributes to improving the quality of management decisions.

It is no coincidence that the UN Convention against Corruption has repeatedly pointed out the need for State Parties to ensure transparency in the activities of state bodies. Thus, according to Part 1 of Art. 5, each State Party, in accordance with the fundamental principles of its legal system, develops and implements or runs an effective and coordinated anti-corruption policy, promoting public participation and reflecting the principles of law and order, proper management of public affairs and public property, integrity, transparency and responsibility. Moreover, in accordance with the basic principles of their internal legislation, each State Party should aim at creation, support and strengthening of such systems, which contribute to transparency and prevent collision of interests (Part 1 Art. 7).

It is noted that transparency of authority is socially important as it increases the trust of citizens to political decisions and decreases the corruption level and ensures better legitimacy of the state apparatus (Anderson, 2009; Basova, 2012; Dawes, 2010; de Fine Licht, 2014; García Garcís, 2014; Meijer et al., 2018; Nomokonov, 2017; Talapina, 2011). It is no coincidence that in accordance with paragraph 3 of Art. 3 of the Federal Law No. 273-FZ "Anti-corruption Enforcement" dated December 25, 2008, the publicity and openness of the activities of state bodies and local governments are among the basic principles of the state anti-corruption policy of the Russian Federation. Although the implementation of this principle at the municipal level today is quite difficult.

One of the most effective ways to ensure the transparency of local governments is the dissemination of socially significant information about their law-making activities through official websites. The main documents constituting the legal and organisational basis for the information openness of municipalities in the Russian Federation are the Federal Law No. 8-FZ "On Ensuring Access to Information on the Activities of Government Agencies and Local Governments" dated February 09, 2009 
and the Concept of Regional Informatisation approved by the Order No. 2769-r of the Government of the Russian Federation dated December 29, 2014. The concept assumes that the publication of regulatory legal acts of local self-government bodies in electronic form will be carried out on the "Official Internet Portal of Legal Information" (http:// pravo.gov.ru). However, after almost five years, this mechanism did not work due to economic, legal and organisational reasons. We believe that there is a need to create an electronic information system, the introduction of which will allow citizens to receive prompt access to the entire system of municipal legal acts in a single form, as well as will enable local governments to carry out local storage of their (acts).

\section{Theoretical framework}

In the introduction we have repeatedly used several terms which are similar in content, though, as it seems, different in practical meaning. In some aspects they determine that public administration bodies are in the centre of public attention.

The theory does not have a unified approach to determining and correlating the categories of openness, accessibility, publicity and transparency. The analysis of sociological (Chuklinov, 2006; Ivonin, 2007; Kleimenov, 2010), politological (Kasaeva \& Afanaseva, 2013; Pyzina, 2006; Vlasova, 2007) and judicial (Akopdzhanova, 2015; Alexandrova, 2008; Bechet-Golovko, 2016; Gunin, 2008; Khairullin, 2017; Kostrova, 2013; Lapina \& Karpukhin, 2015; Lokhmanov, 2015; Manchenko, 2012; Mikheev, 2013; Nesterov, 2015; Polieva, 2011; Talapina, 2015; Tereshchenko, 2011) works allows to conclude that in relation to the public administration the term "openness" is used more frequently as it is attributed with various typical features depending on the functions performed by state bodies and the position of the author. At the same time "information openness" is only a part of a broader notion "openness." As a more general category, "openness" in addition to "information openness" also includes the involvement of citizens in the activities of government bodies. The concept of "accessibility" is used to indicate the possibility of unhindered access of citizens and other persons to information about the authority's activities. The concept of "glasnost" is used most often in relation to the activities of judicial authorities, as well as guarantees of the media to receive and disseminate information about the activities of state and municipal authorities. In most cases, the term "publicity" is used in relation to the activities of representative bodies of power.

There is some linguistic complexity in understanding the term "transparency". In the legislation and legal doctrine, the Russian-language analogue of transparency, 
"prozrachnost", is used much more frequently. However, these two terms cannot be considered synonymous, since, according to representatives of the Russian political science and sociology, "transparency" includes "openness", "prozrachnost" and "accessibility" (some authors also refer to "glasnost"). Therefore, we believe that it is necessary to distinguish transparency in the narrow (as the availability of information about the activities of government bodies) and the broad (as a socio-political equivalent of the category "openness") meanings.

The lack of a developed system of "conceptual coordinates" can lead to the formation of contradictory legal regulation, which will create obstacles in law enforcement. We believe this "Gordian knot" can be cut only by unification under the so-called "terminological convention". In this article, we refer to openness of public administration as the most general term, while it structurally includes information openness (the ability of citizens to access socially important information about public decisions made), procedural openness (the ability of citizens to observe the public decision-making process) and participative openness (the opportunity for the citizens to directly participate in the process of public decisions making).

\section{Statement of the problem}

Speaking about law-making activities of local governments, it should be emphasised that in this area the scope, quality and availability of legal acts for review are inversely proportional. According to the analytical report of the Ministry of Justice of Russia as of July 27, 2018, more than 7 million acts are included in the Federal Register of Municipal Regulatory Legal Acts, of which 5 million 606 thousand are valid (Review, 2018). At the current growth rate of municipal regulatory legal acts, which is about 1 million per year, less than $1 / 3$ of them are represented in the reference legal systems. Moreover, over 40 thousand acts of the RSFSR and the USSR are not incorporated into the system of Russian legislation (Astanin \& Rogovaya, 2016).

Municipal regulatory legal acts are subject to inclusion in the register of municipal regulatory legal acts of a subject of the Russian Federation. They should be organised and maintained by state authorities of the subject of the Russian Federation as established by the regional law (Article 43.1 of the Federal Law No. 131-FZ "On general principles of organisation of local self-government in the Russian Federation" dated October 06, 2003). The Federal Register of Municipal Regulatory Legal Acts consists of registers of municipal regulatory legal acts of the subjects of the Russian Federation. Supervision and methodological support is provided by the Ministry of Justice of Russia. The portal 
"Regulatory legal acts in the Russian Federation" (http://pravo.minjust.ru) implements modern approaches to storage and search for information. As a result, the search for any act takes not more than 2-3 seconds and it is possible to search by names and texts of acts, the interface is very convenient (Review, 2018).

At the same time, the use of the portal, on the one hand, is complicated by differences in the approaches of regional authorities to determining the scope of municipal regulatory legal acts to be included in the register of municipal regulatory legal acts of the subject of the Russian Federation. On the other hand, the register does not include municipal legal acts that have individual content but are of great social and political importance (for example, acts on the competition for the position of head of local administration, acts on the temporary execution of powers of the head of a municipality, etc.) Therefore, the problem of ensuring quick and convenient access to the entire system of municipal legal acts of each municipality, such as it is in relation to federal and regional acts, is not currently relevant.

Currently, there are several ways citizens can get access to municipal legal acts issued by the local governments, including information about making changes to them, declaring them invalid, recognising them as invalid by the court:

- search for official printed editions of local governments in library archives;

- search on the official websites of local governments;

- search in the Register of Municipal Regulatory Legal Acts of subjects of the Russian Federation;

- sending a personal request to the authorities or to officers of local government. Nevertheless, each of the indicated ways has significant shortcomings (Damm et al., 2017).

Obtaining and processing of legal information from library funds is complicated due to the absence of any systematisation of sources of municipal legal acts' official publication. The search for the original edition and its comparison with the subsequently adopted amendments is, for the most part, available only to persons who have a higher or secondary professional legal education. Moreover, the territorial location of libraries causes difficulties for citizens living in remote areas (for example, in the Taimyr Dolgan-Nenets or Evenk districts of the Krasnoyarsk Krai).

Official websites of local governments do not contain the full base of legal acts. In the federal legislation there are no requirements to the procedure and conditions for placement of municipal legal acts in the Internet. Our selective monitoring of official sites of municipalities (local governments) in all federal districts of the Russian 
Federation, as well as continuous monitoring of official sites of municipalities (local governments) in the Krasnoyarsk Krai, showed that despite significant scope of information about municipal legislation in the Internet, there are serious difficulties in obtaining it. This is due to a number of factors that reduce the degree of openness and accessibility of municipal legal acts. These include several websites of local authorities in the municipality; lack of uniformity in the structure of placement of municipal legal acts (location on the website, the name of the section (subsection) and the method of placing acts in the section (subsection)); placement of a partial, rather than a complete system of adopted municipal legal acts; the lack of navigational mechanisms on the website, which allow searching only by legal acts, and many more. Moreover, some municipalities have no official website at all (Damm et al., 2018b).

The Register of Municipal Regulatory Legal Acts of the Subjects of the Russian Federation has a number of shortcomings that do not allow for the full-fledged search for legal acts of local governments. Despite the continuous development of the information systems under consideration, working with databases of municipal regulatory legal acts is complicated by a number of difficulties. In addition to the formal and substantive aspects, which we mentioned above, they also include to some extent the "negligent" attitude of municipalities to providing socially significant information about their law-making activities. According to V.V. Astanin, de jure and de facto, the Ministry of Justice of Russia is deprived of the opportunity to demand from local governments timely submission to the Register of issued municipal regulatory legal acts, and "administrative responsibility of guilty officials of municipalities for failure to submit municipal legal acts to the Register occurs only after prosecutorial response acts" (Astanin, 2015).

The need for a personal appeal to the bodies or officials of local self-government in order to obtain the relevant municipal legal act is in fact contrary to the principles of publicity and public accessibility of legal acts affecting the rights and freedoms of citizens. According to E.V. Talapina, in the conditions of modern public administration, informational openness is characterised by a shift in emphasis towards the responsibilities of the authorities and "is provided not only and not so much due to citizens' access to information, but by advanced distribution of information by the authorities" (Talapina, 2016). Since a personal request for access to a municipal legal act implies the availability of information on its main attributes (name, number, current edition, etc.), which can also be difficult to find and obtain under given conditions, the practical implementation of this method seems to be ineffective. 
Therefore, each of the considered methods does not provide full access of citizens, organisations and expert community to the entire system of municipal legal acts. Moreover, none of the existing reference and registration systems provide local governments with the opportunity to edit, on the basis of permissive access, amended and (or) repealed municipal legal acts. This problem can be solved by the development of an electronic information system that provides local government officials with an opportunity to conveniently store, systematise and search in the array of all municipal regulatory and other legal acts adopted in the respective municipality. The question of the need to create such a system in order to codify and incorporate municipal regulatory legal acts has been repeatedly raised in the scientific literature, and attempts to put it into practice have been repeatedly made both at the federal and at the regional level.

\section{Discussion}

Due to the problems outlined above, the research team of the Law Institute of Siberian Federal University under the guidance of Professor N.V. Shcherdrin within the framework of the grant of the Regional Fund for Scientific and Technology Development Support "Openness and Accessibility of Municipal Regulatory Legal Acts: the State and Ways of Ensuring", has developed and implemented the electronic information system "Municipal Legal Acts of the Krasnoyarsk Krai" in the activities of one of the municipalities (hereinafter referred to as EIS).

The system is based on two user interfaces. The first one is intended for citizens residing in the territory of the municipality, as well as other persons interested in learning about the municipal legal acts of the respective municipality, the second one is for officials of local governments.

The main page of the interface for citizens contains the following modules: simple search; advanced search; the last municipal legal acts added to the EIS database; counter of the EIS municipal legal acts placed in the database. The simple search is designed to quickly find the necessary municipal legal act by keyword in its title or main text, as well as by the number of the relevant act. The advanced search is done by the exact information contained in the following headings: title of the act; number of the act; body that adopted the act; type of the act, etc.

After finding the municipal legal act of interest, the user can view its content. The act card contains all mandatory attributes of a municipal legal act and electronic files with the current edition of the relevant municipal legal act and its later revisions, as well as the original text of the municipal legal act. An indisputable advantage of the EIS is 
that the user can not only view the text of the municipal legal act in MS Word format, but also for the purpose of its authentication, with the scanned copy of the signed and duly certified municipal legal act in PDF format. For easy navigation, the previous versions of the act are arranged in chronological order and are named depending on the date of the adoption of the municipal legal act with the appropriate changes.

For the convenience of the user, the interface for citizens in the act card provides information on municipal legal acts related to the reviewed act (modified or repealed). The existence of such links between municipal legal acts is a distinctive feature of the EIS database and is dictated by the natural process of municipal law-making. The ability to navigate related municipal legal acts increases the efficiency (convenience) of access and the quality of information on the law-making activities of municipalities.

The main page of the interface for municipal officers contains modules for creating and editing legal acts, as well as a menu for searching all the data loaded in the EIS. An important feature of the EIS is the ability to indicate upon registration in the system of a municipal legal act on the sign of its general availability. This means that at the discretion of an interface user for municipal officers, a municipal legal act may or may not be available for public viewing in the interface mode for citizens. Thereby, municipal legal acts with individual content can be placed in the system as well (Damm et al., 2018a).

Ensuring the openness and accessibility of municipal legal acts through the implementation of this EIS has a serious anti-corruption potential.

The possibility of obtaining the necessary legal information quickly and without impediment will create obstacles for unlawful actions by officials of local government bodies. For example, a citizen who has previously got acquainted with the provisions of the relevant administrative regulations before receiving public services knows about the terms of providing services, the list of documents required for submission, etc. Such a citizen can reasonably object to the unlawful requirement of an official of a municipal body to submit additional documents.

One of the important aspects of the implementation of openness and accessibility of municipal legal acts is to increase the legal literacy of the population. A citizen who knows the rules of law is able to understand the unlawfulness of the exaggerated demands, and therefore will be able to appeal against unlawful actions. In turn, a person intending to extort additional remuneration, realising that in front of them there is a citizen who knows the order of the regulatory framework in the relevant field, is likely to abstain from corrupt behaviour. 
The openness and accessibility of municipal legal acts provided within the framework of the EIS, will allow the population to receive information about decisions taken by local governments, and therefore contribute to forming public opinion and evaluating the activities of local governments. It is no coincidence that paragraph 4.1 of Resolution No. 8-7 of the Parliamentary Assembly of the Collective Security Treaty Organization "On the draft Recommendations on harmonisation of legislation of the CSTO Member States governing relations in the field of preventing and combating corruption" indicated that priority of the anti-corruption policy of all the CSTO Member States, contributing to minimisation of corruption and development of an effective system for civil society institutions and individual citizens to control activities of government bodies.

The development of institutions of public and parliamentary control over the observance of the anti-corruption legislation of the Russian Federation is one of the measures to counter corruption, as follows from the provisions of Article 6 of the Federal Law No. 273-FZ “On Combating Corruption” dated December 25, 2008. From the point of view of openness and availability of municipal legal acts, the subject of public control in order to prevent corruption are the results of the activities of local governments. In the process of monitoring legal acts, an assessment of the content of the adopted decisions takes place, and their analysis in combination with other acts. The integrated approach in evaluating decisions made on budget execution, allocation of funds, provision of benefits, allocation of land is especially important. Public inspections that can be carried out after receiving information about the allocation of funds for specific objects, such as road repairs, landscaping and gardening activities, cannot be excluded neither. Moreover, the law-making process itself, the publication of projects (for example, the budget), public hearings can be evaluated as well.

An important role is also played by public expertise conducted in order to comply with the requirements of the law, respect for the rights and freedoms of a person and citizen, and the rights and legal interests of public associations and other non-governmental nonprofit organizations. The anti-corruption expert evaluation of municipal regulatory legal acts and their projects is of special interest. It is provided for by the Federal Law No. 172-FZ “On Anti-Corruption Expert Evaluation of Regulatory Legal Acts and Draft Regulatory Legal Acts" dated July 17, 2009 and may be carried out in the form of an independent anti-corruption expert examination. According to experts, anti-corruption monitoring at the municipal level is one of the directions of development of the state anticorruption policy of the Russian Federation (Kabanov, 2013). 


\section{Conclusion}

The openness of law-making and law-enforcement activities of local selfgovernment bodies implies full availability to citizens, organisations and the expert community of the results of the implementation of their authority. In this aspect, the lack of full access to municipal legal acts makes it impossible to exercise public and expert control in the area of combating corruption and, as a result, to create prerequisites for various corruption abuses. We believe that the use of such systems in the practice of municipalities will ensure that citizens and other interested parties receive the necessary legal information for their own needs and for public control, and, therefore, will reduce corruption risks. The authors of this article on the basis of Siberian Federal University have already developed and are in the process of implementation of the electronic information system "Municipal Legal Acts of the Krasnoyarsk Krai" (certificate of state registration of computer programmes No. 2018662364).

\section{References}

Akopdzhanova, M.O. (2015). Transparentnost kak vazhneishii printsip protivodeistviia korruptsionnym prestupleniiam [Information transparency as part of anti-corruption], Rossiiskaia iustitsiia [Russian justice], 2, pp. 28-31.

Aleksandrova, O.A. (2008). Informatsionnaia otkrytost kak sostavliaiushchaia protivo-deistviia korruptsii [Information openness as part of anti-corruption], $\mathrm{PhD}$ diss., Russian Law Academy.

Anderson, T.B. (2009). E-government as an anti-corruption strategy, Information Economics and Policy, 21 (3), pp. 201-210. DOI: 10.1016/j.infoecopol.2008.11.003.

Astanin, V.V. (2015). Munitsipalnoe pravotvorchestvo: voprosy kachestva i rezervy optimizatsii [Municipal Law-Making: Quality Issues and Optimization Reserves], Monitoring pravoprimeneniia [Monitoring of Law Enforcement], 4, pp. 4-9.

Astanin, V.V., Rogovaya, A.V. (2016). Monitoring obespecheniia i sostoianiia kachestva normotvorcheskoi deiatelnosti organov mestnogo samoupravleniia [Monitoring of the Provision and Quality of the Rule-Making Activities of Local Governments], Monitoring pravoprimeneniia [Monitoring of Law Enforcement], 4, pp. 4-13. DOI: 10.21681/2226-0692-2016-4-04-13.

Basova, T.B. (2012). Protivodeistvie korruptsii v fokuse administrativnoi reformy Rossii [Corruption Counteraction in Focus of Administrative Reform of Russia], Kriminologicheskii zhurnal Baikalskogo gosudarstvennogo universiteta ekonomiki i prava [Criminology Journal of Baikal National University of Economics and Law], 4, pp. 6-12. 
Bechet-Golovko, K. (2016). Printsip glasnosti v Rossii [The Principle of Publicity in Russia], Lex Russica, 1, pp. 90-98.

Chuklinov, A.E. (2006). "Prozrachnaia" gosudarstvennaia politika: nekotorye problemy teorii i praktiki [Transparent State Policy: Some Problems of Theory and Practice], Vestnik Rossiiskogo universiteta druzhby narodov. Seriia: Politologiia [Herald of Russian University of Peoples' Friendship. Series: Political Science], 8, pp. 44-50.

Damm, I.A., Ronzhhina, O.V., Akunchenko, E.A., Korkhov, A.V., Volkova, M.A. (2018a). Elektronnaia informatsionnaia sistema ucheta khraneniia i aktualizatsii munitsipalnykh pravovykh aktov: razrabotka i aprobatsiia na territorii Krasnoiarskogo kraia [Digital system of registering, storage and actualization of municipal legal acts: elaboration and approbation in the territory of Krasnoyarsk krai], Aktualnye problemy ekonomiki i prava [Actual Problems of Economics and Law], 4, pp. 699-719. DOI: 10.21202/1993-047X.12.2018.4.699-719.

Damm, I.A., Ronzhhina, O.V., Akunchenko, E.A., Volkova, M.A., Korkhov, A.V. (2018b). Otkrytost i dostupnost informatsii o pravotvorcheskoi deiatelnosti organov mestnogo samoupravleniia v Rossiiskoi Federatsii [Openness and Accessibility of Information about the Law-Making Activities of Local Governments in the Russian Federation], Rossiiskii iuridicheskii zhurnal [Russian Legal Journal], 6, pp. 85-97.

Damm, I.A., Ronzhina, O.V., Akunchenko, E.A., Sukhareva, K.S. (2017). Aktualnye voprosy obespecheniia otkrytosti i dostupnosti munitsipalnykh normativnykh pravovykh aktov [Topical Issues of Ensuring Openness and Accessibility of Municipal Normative Legal Acts], Pravo i politika [Law and Politics], 8, pp. 46-54. DOI: 10.7256/1999-2793.2013.03.8.

Dawes, S.S. (2010). Stewardship and usefulness: Policy principles for informationbased transparency, Govenrment Information Quarterly, 27, pp. 377-383. DOI: 10.1016/j. giq.2010.07.001.

De Fine Licht, J. (2014). Policy Area as a Potential Moderator of Transparency Effects: An Experiment, Public Administration Review, 74 (3), pp. 361-371. DOI: 10.1111/puar.12194.

García Garcís, J. (2014) Open government: Transparency, Participation and collaboration in public administration [Gouvernement ouvert: Transparence, participation et collaboration dans les administrations publiques], Innovar, 24 (54), pp. 75-88.

Gunin, D.I. (2008). Transparentnost i taina informatsii: teoretiko-pravovoi aspect [Transparency and the Secret Information: The Theoretical and Legal Aspect], PhD diss., Ural State Law Academy. 
Ivonin, M.Iu. (2007). Transparentnost gosudarstvennogo upravleniia kak obieekt sotsiologicheskogo issledovaniia [Transparency of State Governance as an Object of Sociological Research], PhD diss., Novosibirsk State University of Economy and Governance.

Kabanov, P.A. (2013). Pravovoe regulirovanie antikorruptsionnogo monitoringa v subieektakh Rossiiskoi Federatsii na munitsipalnom urovne [Legal Regulation of Anti-Corruption Monitoring in the Regions of the Russian Federation at the Municipal Level], Monitoring pravoprimeneniia [Monitoring of Law Enforcement], 2, pp. 38-43.

Kasaeva, T.V., Afanaseva, A.V. (2013). Transformatsii organizatsionnogo printsipa otkrytosti publichnoi vlasti v kontekste formirovaniia informatsionnogo obshchestva $\mathrm{v}$ Rossii [Transformation of the Organizational Principle of Public Authority Openness in the Context of the Information Society Formation in Russia], Informatsionnaia bezopasnost regionov [Information Security of Regions], 1, pp. 64-68.

Khairullin, R.R. (2017). Konstitutsionnyi printsip otkrytosti organov gosudarstvennoi vlasti v Rossiiskoi Federatsii [The Constitutional Principle of Public Authorities Openness in the Russian Federation], PhD in Law, Kazan Federal University.

Kleimenov, E.A. (2010). Otkrytost kak faktor povysheniia effektivnosti deiatelnosti organov gosudarstvennogo upravleniia [Openness as a Factor in Increasing the Effectiveness of Government Bodies], PhD diss., Far Eastern Academy of Public Service.

Kostrova, N.M. (2013). Publichnost sudebnoi vlasti [Publicity of the Judiciary], Sovremennoe parvo [Modern Law], 12, pp. 99-103.

Lapina, M.A., Karpukhin, D.V. (2015). K voprosu ob ispolzovanii definitsii "transparentnost" i "otkrytost" primenitelno k institutu gosudarstvennoi sluzhby v Rossiiskoi Federatsii [On the Use of Definitions of "Transparency" and "Openness" in Relation to the Institution of Public Service in the Russian Federation], NB: Administrativnoe pravo i praktika administrirovaniia [NB: Administrative Law and Administrative Practices], 5, pp. 17-33. DOI: 10.7256/2306-9945.2015.5.17507.

Lokhmanov, D.V. (2015). Problemy otkrytosti gosudarstvennoi grazhdanskoi sluzhby Rossiiskoi Federatsii [Problems of Openness of the State Civil Service of the Russian Federation], NB: Administrativnoe pravo i praktika administrirovaniia [NB: Administrative Law and Administrative Practices], 5, pp. 70-82. DOI: 10.7256/23069945.2015.5.18068.

Manchenko, P.A. (2012). Konstitutsionno-pravovoi printsip transparentnosti deiatelnosti organov gosudarstvennoi vlasti i organov mestnogo samoupravleniia $\mathrm{V}$ 
Rossiiskoi Federatsii i zarubezhnykh gosudarstvakh [The Constitutional Principle of Transparency of the Activities of Public Authorities and Municipalities in the Russian Federation and Foreign Countries], PhD diss., RANEPA.

Meijer, A., Hart, P., Worthy, B. (2018). Assessing Government Transparency: An Interpretive Framework, Administration and Society, 50 (4), pp. 501-526. DOI: 10.1177/0095399715598341.

Mikheev, D.S. (2013). Ob otdelnykh aspektakh v pravovom regulirovanii printsipa glasnosti mestnogo samoupravleniia [On Certain Aspects of the Municipality's Publicity Legal Regulation], Zakon i parvo [Legislation and Law], 9, pp. 35-37.

Nesterov, A.V. (2015). O strategicheskikh i takticheskikh zakonodatelnykh problemakh otkrytosti "Otkrytogo pravitelstva" [On the Strategic and Tactical Legislative Problems of "Open Government” Openness], Iuridicheskaia tekhnika [Legal Technology], 9, pp. 506-510.

Nomokonov, V.A. (2017). Prichiny prestupnosti v sovremennoi Rossii: problema obostriaetsia [Causes of Crime in Contemporary Russia: The Problem is Getting Worse], Kriminologicheskii zhurnal Baikalskogo gosudarstvennogo universiteta ekonomiki i prava [Criminology Journal of Baikal National University of Economics and Law], 11 (2), pp. 247-257.

Polieva, O.M. (2011). Printsipy otkrytosti i glasnosti sudebnoi sistemy Rossii v novykh usloviiakh [Principles of Openness and Publicity of the Russian Judicial System in the New Conditions]. Iurist-Pravoved [Lawyer-Legislator], 5, pp. 17-20.

Pyzina, G.V. (2006). Transparentnost ispolnitelnoi vlasti: sushchnost i mekhanizmy realizatsii v sovremennoi Rossii [Transparency of Executive Power: The Essence and Mechanisms of Implementation in Modern Russia], PhD diss., RANEPA.

Review, 2018 - Obzor praktiki vedeniia federalnogo registra munitsipalnykh normativnykh pravovykh aktov za 2018 god [Review of the Practice of Maintaining the Federal Register of Municipal Normative legal acts for 2018]. Available at: http://pravo. minjust.ru/analytics_statistics/reviews/obzor-praktiki-vedenia-federalnogo-registramunicipalnyh-normativnyh-pravovyh-aktov-za-2018-god/ (accessed January 11, 2019).

Talapina, E.V. (2011). Antikorruptsionnyi informatsionnyi standart v gosudarstvennom upravlenii: podkhody $\mathrm{k}$ ponimaniiu [Anticorruption Information Standard in Public Administration: Approaches to Understanding], Gosudarstvo $i$ pravo [State and Law], 3, pp. 5-15.

Talapina, E.V. (2015). Printsip transparentnosti v publichnom prave [The Principle of Transparency in Public Law], Gosudarstvo i pravo [State and Law], 5, pp. 40-47. 
Talapina, E.V. (2016). O proekte federalnogo zakona ob osnovakh gosudarstvennogo upravleniia [About the Draft Federal Law on the Basics of Public Administration], Zhurnal rossiiskogo prava [Journal of Russian Law], 3, pp. 95-104. DOI: 10.12737/18033.

Tereshchenko, L.K. (2011). Pravovoi rezhim informatsii [Legal regime of information], Dr.Sc. diss., Institute of Legislation and Comparative Jurisprudence under the Government of the Russian Federation.

Vlasova, N.V. (2007). Problema transparentnosti politicheskogo protsessa V sovremennoi Rossii [The Problem of Transparency of the Political Process in Modern Russia], PhD diss., Saratov State University.

\title{
Антикоррупционный потенциал открытости и доступности муниципальных правовых актов
}

\author{
И.А. Дамм, Н.В. Щедрин, О.В. Роньжина, \\ Е.А. Акунченко, А.В. Корхов \\ Сибирский федеральный университет
} Россия, 660041, Красноярск, пр. Свободный, 79

Статья посвящена проблемам обеспечения информаџионной открытости результатов правотворческой деятельности органов местного самоуправления. На сегодня в России отсутствует электронная платформа, позволяющая получить доступ ко всей системе муниципальных правовых актов в едином виде. В свою очередь, правовое регулирование в указанной сфере противоречиво и не отличается понятийно-категориальным единством. В качестве возможного решения предлагается электронная информационная система «Муниципальные правовые акты Красноярского края». В ее структуре выделяются два пользовательских интерфейса, первый из которых предназначен для доступа населения муниципального образования и иных заинтересованных лиц к базе данных муниципальных правовых актов, а второй - для муниципальных служащих, формирующих указанную базу данных. Функциональные особенности электронной информационной системы и логика построения базы данных позволяют пользователям наблюдать актуальную редакцию мунищипального правового акта, просматривать историю внесенных в него изменений, а также отслеживать связи, возникающие между актами в проиессе правотворческой деятельности органов местного самоуправления. В отличие от большинства аналогов данная система позволяет хранить и обнародовать правовые акты с индивидуальным содержанием, а также, в случае необходимости, обеспечивать их конфиденциальность. Внедрение подобной системы в практику муниципалитетов имеет антикоррупционный потенцииал, который выражается в повышении правовой осведомленности населения муниципального образования, активизации общественного контроля за деятельностью органов местного самоуправления, а также обеспечении независимой антикоррупиионной экспертизы муниципальных нормативных правовых актов и их проектов. 
Ключевые слова: местное самоуправление, муниципалитет, правовой акт, открытость, доступность, гласность, публичность, прозрачность, транспарентность, электронная информащионная система, коррупчи, предупреждение.

Исследование выполнено при поддержке Краевого государственного автономного учреждения «Красноярский краевой фонд поддержки научной и научно-технической деятельности» в рамках реализации проекта: «Открытость и доступность муниципальных нормативных правовых актов: состояние и способы обеспечения».

Научная спещиальность: 12.00.00 - юридические науки. 